\title{
Serological investigation of equine viral arteritis in donkeys in eastern and south-eastern Anatolia regions of Turkey
}

\author{
Sibel Gür ${ }^{1}$, Bünyamin İrehan², Metin Gürçay³, Turhan Turan ${ }^{4}$ \\ ${ }^{1}$ Afyon Kocatepe University, Faculty of Veterinary Medicine, Department of Virology, Afyonkarahisar, Turkey \\ ${ }^{2}$ Veterinary Control Institute Elazı̆g, Virology Laboratory, Elazı̆̆ , Turkey \\ ${ }^{3}$ Bingöl University, Faculty of Veterinary Medicine, Department of Virology, Bingöl, Turkey \\ ${ }^{4}$ Cumhuriyet University, Faculty of Veterinary Medicine, Department of Virology, Sivas, Turkey
}

Received November 13, 2017

Accepted October 29, 2019

\begin{abstract}
Equine arteritis virus is classified in the Arteriviridae family and causes reproductive and respiratory disorders. The host spectrum includes many species of the Equidae family. Horses, donkeys and mules are the most sensitive species. The infection was serologically investigated in adult donkeys on small private family type enterprises in eastern and south-eastern Anatolia in this study. A total of 1,532 samples were collected from 28 different locations in 6 different provinces in these two regions. The number of donkeys sampled from each farm was between 1 and 3. Serum samples were tested by indirect enzyme-linked immunosorbent assay (ELISA). As a result of sero-controls, 53 animals were positive $(3.45 \%)$. The presence of infection was determined in all the provinces; Elazı̆ $(7 \%, 17 / 241)$, Tunceli $(2.4 \%, 3 / 122)$, Van $(2.9 \%, 10 / 342)$, Bitlis $(4.6 \%, 5 / 107)$, Şırnak $(2.7 \%, 12 / 440)$ and Siirt $(2.1 \%, 6 / 280)$. Seropositivity was detected in 22 of the 28 locations. In this study, data were obtained from a significant number of animals for the first time in these regions. Although the values were not high, the findings revealed the presence of infection in the majority of the investigated sites. Despite the fact that the incidence was not high in donkeys probably due to restricted management conditions, the incidence may increase over time and may pose a risk for thoroughbred horses unless necessary measures are taken.
\end{abstract}

Equus asinus, seroprevalence, viral infection

Equine viral arteritis (EVA) is one of serious infections that can affect horses. Donkeys, mules and alpacas are also susceptible to natural infection as well as the main host (Paweska and Barnard 1993; Paweska et al. 1996; Paweska et al. 1997; Weber et al. 2006).

The equine arteritis virus (EAV) is an enveloped, single stranded virus. The genome is of positive sense ribonucleic acid (RNA), which is classified in the Arteriviridae in the Nidovirales order (Cavanagh et al. 1994). The EVA virus has only one serotype (Westcott et al. 1995). There are limited antigenic variations among certain isolates but the severity of disorders shows alterations according to strain (Murphy et al. 1992; Stadejek et al. 1999). These differences in prognosis and abortion rates have been observed in outbreaks (Timoney et al. 1987b; Eichhorn et al. 1995; McCollum et al. 1995; Wood et al. 1995; Del Piero et al. 1997).

The most important mode of transmission is via the respiratory route, in both natural and experimental infections (Guthrie et al. 2003). Nevertheless, sexually transmitted infections from imported stallions are important for spread between farms and countries (Metcalf 2001; Holyoak et al. 2008). Clinical signs may vary in relation to age, strain and dose of the virus, individual factors, environmental conditions, herd size and intensity (Vaala et al. 1992; Timoney and McCollum 1993; MacLachlan et al. 1996; Paweska et al. 1996). After an incubation period of 3 to 14 days, fever, nasal and ocular injuries,

Address for correspondence:

Sibel Gür

Department of Virology

Faculty of Veterinary Medicine

Afyon Kocatepe University

Phone: +902722281312

03200, ANS Campus, Afyonkarahisar, Turkey

http://actavet.vfu.cz 
rhinitis, conjunctivitis, cough, diarrhoea, ataxia, urticaria, respiratory distress, oedema in orbita, limbs, scrotum, prepuce and mammary gland can be observed (Vaala et al. 1992; Del Piero et al. 1997; Szeredi et al. 2005; Holyoak et al. 2008).

The presence of EAV infection has been reported in horse populations all over the world since its first description in the United States in 1953 (Doll et al. 1957). Seroprevalence values are quite variable based on the country, race and management conditions. Japan and Iceland are virus-free (Kondo et al. 1998), contrary to the remaining parts of the continents (Timoney and McCollum 1988). Seroprevalence is generally less than $20 \%$ (Eichhorn et al. 1995; McCollum et al. 1995; Hullinger et al. 2001; Cruz et al. 2016). The incidence of EVA has been increasing especially in the last two decades (Glaser et al. 1997; Rola et al. 2011). According to the latest reports, the virus is in circulation in different parts of the world like Poland (Rola et al. 2011), Algeria (Laabassi et al. 2014), France (Amat et al. 2016), Spain (Cruz-Lopez et al. 2017), Serbia (Lazić et al. 2017) and Chile (Rivas et al. 2017). There is limited information about Turkey. Specific antibody rates vary between 5\% (Y1lmaz et al. 1996) and 14.4\% (Y1ldirim et al. 2008) in horses and donkeys.

The aim of this study was to serologically investigate EAV infection in donkeys to reveal a realistic profile by controlling relatively extensive numbers of animals in private small farms in eastern and south-eastern Anatolia.

\section{Materials and Methods}

Sampled animals

Donkeys are used as draft animals and often breed with ruminant species on farms in rural areas. The average number of donkeys is 1 to 3 per farm. Clinically healthy adult ( $\geq 1$ year old) donkeys were randomly selected for sampling. Mostly female animals were available on farms depending on management practices. Of the six studied provinces, four were located in the East, and two were in the southeast Anatolia region (Siirt and Şırnak). Although detailed health records of animals were not kept, animal owners reported that some symptoms that may be associated with EVA and abortus cases were encountered from time to time. Blood samples were collected by venipuncture from vena jugularis into tubes containing silicone, and transported to the laboratory at $4{ }^{\circ} \mathrm{C}$. After centrifugation at $3000 \mathrm{rpm}$ for $10 \mathrm{~min}$, sera samples were separated into stock tubes and stored at $-20^{\circ} \mathrm{C}$ until testing.

Enzyme Linked Immunosorbent Assay (ELISA)

The ELISA is used to detect EVA virus specific antibodies due to its high sensitivity and specificity (Kondo et al. 1998). The test was carried out according to the manufacturer's instructions (Indirect Equine Viral Arteritis, ID Vet, France). At the end of the test, the plates were read in $450 \mathrm{~nm}$ and the obtained values were calculated.

\section{Results}

This study was carried out in six provinces located in east Anatolia $(n=4)$ and southeast Anatolia $(\mathrm{n}=2)$ regions. Elazı $\breve{g}$, Tunceli, Van and Bitlis are located in the east Anatolia region. The samples from Elazığ were collected from 6 localities; the central villages $(0 / 24)$, Maden (1/51), Karakoçan (1/40), Alacakaya (3/56), Sivrice (8/40) and Baskil (4/30). Total seropositivity was found to be $7 \%(17 / 241)$. In the Tunceli province, 4 locations were selected; Central (1/40), Hozat (1/32), Mazgirt (0/24) and Pertek (1/26). In total, of 122 samples, three were detected as seropositive $(2.4 \%)$ (Table 1$)$.

A total of 342 donkeys were sampled in the Van province; Center (3/42), Bahçesaray (0/92), Erciş (1/96), Gürpınar (1/20) and Muradiye (5/92), and 2.9\% were detected as positive. The smallest number of samples were collected from Bitlis, Center (3/92) and the Hizan county $(2 / 15)$.

The Şirnak and Siirt provinces are in the southeast Anatolia region. A total of 440 donkeys were sampled in Şırnak. In total, $2.7 \%$ of the animals were positive in the province and its districts of Center (1/100), Cizre (1/49), İdil (5/195), Uludere (2/50) and Silopi (3/46). The 
lowest percentage was detected in Siirt at 2.1\% (6/280) and its districts, namely Center (3/92), Baykan (0/20), Şirvan (0/38), Kurtalan (1/34), Eruh (2/46) and Aydınlar (0/50).

Of the 1.532 donkeys in total, 53 were found to be seropositive for EAV infection. Of the 28 locations, all samples were found to be negative in only 6 districts. The percentages ranged from $1 \%$ to $20 \%$ in the other 22 locations.

\section{Discussion}

Pathogenetic studies are mostly focused on horses. Donkeys are at least as sensitive as horses and the pathogenesis is the same (McCollum et al. 1995; Paweska et al. 1995; Paweska et al. 1996). We know that the incidence of EVA infection is higher in stallions due to the long duration of the carrier state (Rola et al. 2011). Antigen positivity can be detected for up to six years and more after acute infection. Some stallions can shed the virus throughout their lifetimes (Timoney et al. 1986; Timoney et al. 1987a,b). However, in an EVA epidemic in Kentucky in 1985, affected mares were screened regularly and all of them were identified as antigen negative soon after the acute stage (Timoney et al. 1987b). An effective control of EVA infection depends on the detection of persistently infected asymptomatic stallions. Field studies show that the incidence increases with age. Rates are higher in males than in females. Standardbred horses are at a greater risk than purebred horses due to prophylactic applications and management factors (Timoney and McCollum 1988; Cruz-Lopez et al. 2017).

There are several studies on EAV infection in donkeys around the world. Paweska and Barnard (1993) found $17 \%$ positivity in donkeys in South Africa; in some regions $30 \%$ rates have been detected. An experimental study carried out with horses and donkeys (Paweska et al. 1996) reported that donkeys were more susceptible to the infection compared to horses and that their seroprevalence was higher. Furthermore, researchers have noted that the infection in donkeys is prolonged. According to past experiences, uncontrolled importation of commercial stallions is the most effective factor in triggering an epidemic (Wood et al. 1995). Similarly, using uncontrolled semen for artificial insemination has the ability to transmit infection between countries (Metcalf 2001). Therefore, many countries have introduced compulsory control for the semen and stallion trade.

The history of EVA in Turkey is unknown due to the absence of retrospective studies. Serological evidence has been available since 1996. In the first report, 5\% (5/100) positivity was detected in horses (Y $11 \mathrm{maz}$ et al. 1996). Another study reported values of $9.5 \%$ $(19 / 200)$ and $8 \%(16 / 200)$ in the Kars and Ardahan provinces (northeastern Anatolia), respectively (K1rmizigül et al. 2007). Hasan (2008) did not isolate any of the 252 horses from seven stud farms in the Marmara region despite a seropositivity of $7.5 \%$. Only two serological studies have been carried out regarding donkeys which manifested $14.4 \%$ (11/76) (Yıldırım et al. 2008) and 8.4\% (19/227) (Gür et al. 2018). A single molecular study has been carried out in which the open reading frame (ORF) $1 \mathrm{~b}$ gene was analysed from samples from nine positive horses with respiratory disorders in four different regions of Turkey. There were minor differences between TR-EVA strains (94.7\%). These strains were found to be closely related to strains of North American origin (vaccines and virulent strains of Bucyrus) (Ataseven et al. 2013).

In this study, $7 \%$ and $2.4 \%$ of the samples collected from animals in the Elaziğ and Tunceli provinces, respectively, were positive. The two highest values (13\% and 20\%) were determined in the Elazı $\breve{g}$ province. These adjacent provinces are located in the eastern Anatolia region. The other four provinces are also border neighbours. The obtained values were quite similar to each other (Van 2.9\%, Şırnak 2.7\%, Siirt 2.1\% and Bitlis 4.6\%). In total, the rate $(3.4 \%)$ was the lowest in Turkey so far (Table 1$)$. All of the samples were negative in six of the 28 locations in total. Seropositivity was below $5 \%$ in 15 districts, whereas 
Table 1. The numbers and locations of sampled donkey and EVA test results.

\begin{tabular}{|c|c|c|c|c|c|c|c|}
\hline \multirow{2}{*}{ Provinces } & \multirow{2}{*}{ Boroughs } & \multirow{2}{*}{ No of samples } & \multicolumn{2}{|c|}{ EAV } & \multirow{2}{*}{ No of samples } & \multicolumn{2}{|c|}{ Total EAV } \\
\hline & & & $\mathrm{Ab}(+)$ & $\%$ & & $\mathrm{Ab}(+)$ & $\%$ \\
\hline Elazığ & Central & 24 & 0 & 0 & 241 & 17 & 7.05 \\
\hline $38^{\circ} 67^{\prime} 43$ & Maden & 51 & 1 & 1.9 & & & \\
\hline \multirow[t]{4}{*}{$-39^{\circ} 22^{\prime} 32$} & Karakoçan & 40 & 1 & 2.5 & & & \\
\hline & Alacakaya & 56 & 3 & 0 & & & \\
\hline & Sivrice & 40 & 8 & 20 & & & \\
\hline & Baskil & 30 & 4 & 13.3 & & & \\
\hline Tunceli & Central & 40 & 1 & 2.5 & 122 & 3 & 2.45 \\
\hline $39^{\circ} 09^{\prime} 92$ & Hozat & 32 & 1 & 3.1 & & & \\
\hline \multirow[t]{2}{*}{$-39^{\circ} 54^{\prime} 35$} & Mazgirt & 24 & 0 & 0 & & & \\
\hline & Pertek & 26 & 1 & 3.8 & & & \\
\hline Van & Central & 42 & 3 & 7.1 & 342 & 10 & 2.92 \\
\hline $38^{\circ} 49^{\prime} 45$ & Bahçesaray & 92 & 0 & 0 & & & \\
\hline \multirow[t]{3}{*}{$-43^{\circ} 3832$} & Erciş & 96 & 1 & 1 & & & \\
\hline & Gürpınar & 20 & 1 & 5 & & & \\
\hline & Muradiye & 92 & 5 & 5.4 & & & \\
\hline Bitlis & Central & 92 & 3 & 3.2 & 107 & 5 & 4.67 \\
\hline $\begin{array}{l}42^{\circ} 10^{\prime} 95 \\
-38^{\circ} 40^{\prime} 05\end{array}$ & Hizan & 15 & 2 & 13.3 & & & \\
\hline Şırnak & Central & 100 & 1 & 1 & 440 & 12 & 2.72 \\
\hline $37^{\circ} 51^{\prime} 89$ & Cizre & 49 & 1 & 2 & & & \\
\hline \multirow[t]{3}{*}{$-42^{\circ} 45^{\prime} 37$} & İdil & 195 & 5 & 2.5 & & & \\
\hline & Uludere & 50 & 2 & 4 & & & \\
\hline & Silopi & 46 & 3 & 6.5 & & & \\
\hline Siirt & Central & 92 & 3 & 3.2 & 280 & 6 & 2.14 \\
\hline $37^{\circ} 93^{\prime} 262$ & Baykan & 20 & 0 & 0 & & & \\
\hline \multirow[t]{4}{*}{$-41^{\circ} 94^{\prime} 0$} & Şirvan & 38 & 0 & 0 & & & \\
\hline & Kurtalan & 34 & 1 & 2.9 & & & \\
\hline & Eruh & 46 & 2 & 4.3 & & & \\
\hline & Aydınlar & 50 & 0 & 0 & & & \\
\hline Total & & & & & 1.532 & 53 & 3.45 \\
\hline
\end{tabular}

EVA - equine viral arteritis; EAV - equine arteritis virus

the rate was between $5 \%$ and $10 \%$ in three localities, and rates between $10 \%$ and $15 \%$ were observed in two districts. Previously, 11.3\% (14/124) rates were detected in horses in the Van province (Gür et al. 2015). Gür et al. (2018), reported 14.3\% (13/91) in Elazı̆g and $15.7 \%(16 / 102)$ in Tunceli provinces in horses. Additionally, in Elazığ and Tunceli provinces, $5.3 \%(7 / 131)$ and $12.5 \%(12 / 96)$ were determined in donkeys, respectively. Data related to the infection were obtained for the first time in the Bitlis, Şırnak and Siirt provinces. In these small provinces which are mostly located in a mountainous terrain, traditional small scale private farms are still very common. The number of donkeys has decreased dramatically in the last few decades as a result of agricultural mechanization, but they are still preferred in daily farm work in rural areas in the county. Routine vaccination has not been applied to any infectious disease in donkeys. Special importance is not given 
to their reproduction due to their low economic value. No preference was made regarding sex in the sampling, however, the majority of the animals were female and most of the farms had no stallion. A limited number of donkey stallions are commonly used in most villages for reproduction. The farms are not very close to each other and none of them had horses. Separate breeding of donkeys from horses may reduce the possibility of cross-species transmission. Disadvantageous factors for in-contact transmission such as intensive breeding, mixed-sex and dual breeding with horses were not deemed important in the studied population. However, the common use of stallions appears to be a noticeable risk factor for sexual transmission. No EVA epidemic has generated concern in Turkey so far despite the presence of the infection in most of the controlled localisations. Regional problems may remain unidentified or unreported especially in donkeys and standardbred horses. A strict control of imported semen contributes significantly to prevention with other prophylactic applications on stud and thoroughbred farms.

In conclusion, the lowest rates in the country were determined in this study probably as a consequence of focused race and preferred breeding conditions. However, the widespread presence of the disease suggests that EVA holds a potential risk for the future. Therefore, it is necessary to obtain extensive field data for other regions of the country and implement preventive studies also for private farms which are still an important part of our agriculture.

\section{Conflict of Interest}

The authors declare that they have no commercial or financial competing interests.

\section{Acknowledgements}

The authors thank Dr. Ünal Kilinç from the Elazı ̆̆ Veterinary Control Institute for support in the field studies and scientific consultancy and to Christine Lester for language revision.

\section{References}

Amat JP, Vergne T, Tapprest J, Ferry B, Hans A, Hendrikx P, Dufour B, Leblond A 2016: Estimating the incidence of equine viral arteritis and the sensitivity of its surveillance in the French breeding stock. Vet Microbiol 192: 34-42

Ataseven VS, Oğuzoğlu TÇ, Karapınar Z, Bilge-Dağalp S 2013. Partial sequence of the ORF1b gene fragment of equine arteritis viruses detected in Turkey and phylogenetic analysis. Revue Med Vet 164: 67-71

Cavanagh D, Brien DA, Brinton M, Enjuanes L, Holmes KV, Horzinek MC, Lai MMC, Laude H, Plagemann PGW, Siddell S, Spaan WJM, Taguchi F, Talbot PJ 1994: Revision of the taxonomy of the Coronavirus, Torovirus and Arterivirus genera. Arch Virol 135: 227-237

Cruz-Lopez F, Newton R, Sanchez-Rodriguez A, Ireland J, Mughini-Gras L, Moreno MA, Fores P 2017: Equine viral arteritis in breeding and sport horses in central Spain. Res Vet Sci 115: 88-91

Cruz F, Fores P, Mughini-Gras L, Ireland J, Moreno M, Newton R 2016: Seroprevalence and factors associated with seropositivity to equine arteritis virus in Spanish Purebred horses in Spain. Equine Vet J 48: 573-577

Del Piero F, Wilkins PA, Lopez JW, Glaser AL, Dubovi EJ, Schlafer DH, Lein DH 1997: Equine arteritis virus in newborn foals: clinical, pathological, serological, microbiological and immunohistochemical observations. Equine Vet J 29: 178-185

Doll ER, Knappenberger RE, Bryans JT 1957: An outbreak of abortion caused by the equine arteritis virus. Cornell Vet 47: 69-75

Eichhorn W, Heilmann M, Kaaden OR 1995: Equine viral arteritis with abortions: serological and virological evidence in Germany. Zentralbl Vet Med B 42: 573-576

Glaser AL, Chirnside ED, Horzinek MC, de Vries AAF 1997: Equine arteritis virus. Theriogenology 47: 1275-1295

Guthrie AJ, Howell PG, Hedges JF, Bosman AM, Balasuriya UBR, McCollum WH, Timoney PJ, MacLachlan NJ 2003: Lateral transmission of equine arteritis virus among Lipizzaner stallions in South Africa. Equine Vet J 35: 596-600

Gür S, Çabalar M, Kaya A, Gürçay M 2015. Serological investigation of equine viral arteritis infection in Van Province (in Turkish). Kocatepe Vet J 8: 36-40

Gür S, Gürçay M, İrehan B, Turan T 2018. Serological investigation of equine viral arteritis infection in donkeys and horses in the eastern Anatolia region. Harran Univ Vet Fak Derg 7: 186-191 
Hasan S 2008: Investigations on the frequency and diagnosis of Equine Arteritis Virus (EAV) infection in horses by virus isolation, molecular and serological techniques in the Marmara region. $\mathrm{PhD}$ thesis. Istanbul University, Health Science Institute, Turkey

Holyoak GR, Balasuriya UBR, Broaddus CC, Timoney PJ 2008: Equine viral arteritis: Current status and prevention. Theriogenology 70: 403-414

Hullinger PJ, Gardner IA, Hietala SK, Ferraro GL, MacLachlan NJ 2001: Seroprevalence of antibodies against equine viral arteritis virus in horses residing in the United States and imported horses. J Am Vet Med Assoc 219: 946-949

Kırmızıgül AH, Yıldırım Y, Gökçe G 2007: Seroprevalence of equine viral arteritis in horses of the Kars and Ardahan Provinces (In Turkish). Kars Univ Vet Fak Derg 13: 171-175

Kondo T, Fukunaga Y, Sekiguchi K, Sugiura T, Imagawa H 1998: Enzyme-linked immunosorbent assay for serological survey of equine arteritis virus in racehorses. J Vet Med Sci 60: 1043-1045

Laabassi F, Amelot G, Laugier C, Zientara S, Nasri AM, Hans A 2014: Prevalence of equine viral arteritis in Algeria. Rev Sci Tech 33: 967-974

Lazić S, Lupulović D, Gaudaire D, Petrovic T, Lazić G, Hans A 2017: Serological evidence of equine arteritis virus infection and phylogenetic analysis of viral isolates in semen of stallions from Serbia. BMC Vet Res 13: 316

MacLachlan NJ, Balasuriya UBR, Rossitto PV, Hullinger PA, Patton JF, Wilson WD 1996: Fatal experimental equine arteritis virus infection of a pregnant mare: Immunohistochemical staining of viral antigens. J Vet Diagn Invest 8: $367-374$

McCollum WH, Timoney PJ, Tengelsen LA 1995: Clinical, virological and serological responses of donkeys to intranasal inoculation with the KY-84 strain of equine arteritis virus. J Comp Pathol 112: 207-211

Metcalf ES 2001: The role of international transport of equine semen on disease transmission. Anim Reprod Sci 68: $229-237$

Murphy TW, McCollum WH, Timoney PJ, Klingeborn BW, Hyllseth B, Golnik W, Erasmus B 1992: Genomic variability among globally distributed isolates of equine arteritis virus. Vet Microbiol 32: 101-115

Paweska JT, Barnard BJH 1993: Serological evidence of equine arteritis virus in donkeys in South Africa. Onderstepoort J Vet Res 60: 155-158

Paweska JT, Volkmann DH, Barnard BJH, Chirnside ED 1995: Sexual and In-contact of Asinine strain of equine arteritis virus among donkeys. J Clin Microbiol 33: 3296-3299

Paweska JT, Aitchison H, Chirnside ED, Barnard BJ 1996: Transmission of the South African asinine strain of equine arteritis virus (EAV) among horses and between donkeys and horses. Onderstepoort J Vet Res 63: 189-196

Paweska JT, Binns MM, Woods PS, Chirnside ED 1997: A survey for antibodies to equine virus in donkeys, mules and zebra using virus neutralisation (VN) and enzyme linked immunosorbent assay (ELISA). Equine Vet J 29: 40-43

Rivas J, Neira V, Mena J, Brito B, Garcia A, Gutierrez C, Sandoval D, Ortega R 2017: Identification of a divergent genotype of equine arteritis virus from South American donkeys. Transbound Emerg Dis 64: 1655-1660

Rola J, Larska M, Rola JG, Bélak S, Autorino GL 2011: Epizotiology and phylogeny of equine arteritis virus in Hucul horses. Vet Microbiol 148: 402-407

Stadejek T, Björklund H, Bascunana CR, Caibatti IM, Scicluna MT, Amaddeo D, McCollum WH, Autorino GL, Timoney TJ, Paton DJ, Klingeborn B, Belák S 1999: Genetic diversity of equine arteritis virus. J Gen Virol 80: 691-699

Szeredi L, Hornyák Á, Pálfi V, Molnár T, Glávits R, Dénes B 2005: Study on the epidemiology of equine arteritis virus infection with different diagnostic techniques by investigating 96 cases of equine abortion in Hungary. Vet Microbiol 108: 235-242

Timoney PJ, McCollum WH, Roberts AW 1986: Detection of the carrier state in stallions persistently infected with equine arteritis virus. Proc Am Assoc Equine Pract 32: 57-65

Timoney PJ, McCollum WH, Murphy TW, Roberts AW, Willard JG, Carswell GD 1987a: The carrier state in equine arteritis virus infection in the stallion with specific emphasis on the venereal mode of virus transmission. J Reprod Fert Suppl 35: 95-102

Timoney PJ, McCollum WH, Roberts AW, McDonald MJ 1987b: Status of equine viral arteritis in Kentucky, 1985. J Am Vet Med Assoc 191: 36-39

Timoney PJ, McCollum WH 1988: Equine viral arteritis: epidemiology and control. J Equine Vet Sci 8: 54-59

Timoney PJ, McCollum WH 1993: Equine viral arteritis. Vet Clin N Am Equine Pract 9: 295-309

Vaala WE, Hamir AN, Dubovi EJ, Timoney PJ, Ruiz B 1992: Fatal, congenitally acquired infection with equine arteritis virus in a neonatal thoroughbred. Equine Vet J 24: 155-158

Weber H, Beckmann K, Haas L 2006: Case report: equine arteritis virus (EAV) as the cause of abortion in alpacas? DTW 113: 162-163

Westcott D, Lucas M, Paton D 1995: Equine arteritis virus: antigenic analysis of strain variation. In: Schwyzer M, Ackermann M, Bertoni G, Kocherhans R, McCullough K, Engels M, Wittek R, Zanoni R (Eds): Immunobiology of viral infections, Proceedings of the $3^{\text {rd }}$ Congress of the European Society for Veterinary Virology, Foundation Marcel Meriéux, Lyon, France, pp. 479-483 
Wood JL, Chirnside ED, Mumford JA, Higgins AJ 1995: The first outbreak of equine viral arteritis in the UK. Vet Rec 136: 381-385

Yıldırım Y, Kırmızıgül AH, Tan MT, Gökçe E, Irmak K 2008: Seroprevalence of Equine Viral Arteritis in donkeys in Kars district, Turkey. J Anim Vet Adv 7: 1110-1112

Yılmaz H, Özgür NY, Ilgaz A 1996: Serological investigation on the equine viral arteritis. 1st international Veterinary Microbiology Congress, September 25-27, İstanbul/Turkey 